\title{
Proteomic study reveals downregulation of apolipoprotein A1 in plasma of poorly controlled diabetes: A pilot study
}

\author{
HEMANGI S. BHONSLE ${ }^{1 *}$, ARVIND M. KORWAR ${ }^{1 *}$, ASHOK D. CHOUGALE ${ }^{1}$, SACHIN S. KOTE $^{1}$, \\ NITIN L. DHANDE ${ }^{2}$, KISHORE M. SHELGIKAR ${ }^{2}$ and MAHESH J. KULKARNI ${ }^{1}$ \\ ${ }^{1}$ Proteomics Facility, Division of Biochemical Sciences, Council of Scientific and Industrial Research, \\ National Chemical Laboratory; ${ }^{2}$ Maharashtra Medical Research Society, Pune 411008, India
}

Received July 19, 2012; Accepted October 10, 2012

DOI: $10.3892 / \mathrm{mmr} .2012 .1223$

\begin{abstract}
Proteomic approaches aid in gaining a better understanding of the pathophysiology of diabetic complications. In view of this, differential protein expression in diabetic plasma samples was studied by a combination of proteomic and western blot analyses. Diabetic plasma samples were categorized based on glycated haemoglobin levels as controlled diabetes (CD; 7-8\%), poorly controlled diabetes (PCD; >8\%) and non-diabetic control (ND;<6.4\%). Two-dimensional electrophoresis and liquid chromatography-mass spectrometry revealed differential expression of proteins including upregulation of fibrinogen and haptoglobin and downregulation of vitamin $\mathrm{D}$ binding protein, $\alpha$-1-antitrypsin, transthyretin and apolipoprotein A1 (Apo A1) in diabetic compared with nondiabetic plasma samples. Amongst these proteins, Apo A1 downregulation was prominent in PCD. Downregulation of Apo A1 may serve as an early predictive marker of diabetic complications.
\end{abstract}

\section{Introduction}

Human plasma proteome analysis has the potential to ease disease diagnosis and therapeutic monitoring $(1,2)$. Plasma protein biomarkers are useful for the diagnosis and prognosis of numerous diseases, including diabetes. Inability to utilize blood glucose is a hallmark of diabetes and leads to the development of numerous complications, including neuropathy, retinopathy, nephropathy and atherosclerosis (3). Development of these complications is 2.5 times higher in patients with long-term poorly controlled glycaemic levels than controlled levels (4). Furthermore, on the basis of glycated

Correspondence to: $\mathrm{Dr}$ Mahesh J. Kulkarni, Proteomics Facility, Division of Biochemical Sciences, Council of Scientific and Industrial Research, National Chemical Laboratory, Homi Bhabha Road, Pune 411008, India

E-mail:mj.kulkarni@ncl.res.in

${ }^{*}$ Contributed equally

Key words: HbA1c, biomarker, proteomics haemoglobin (HbA1c) levels diabetic subjects are categorized as having controlled diabetes (CD) and poorly controlled diabetes (PCD) with $\mathrm{HbA} 1 \mathrm{c}$ levels $\leq 8 \%$ and $>8 \%$, respectively, of total haemoglobin (5). To understand the molecular mechanisms of pathophysiology of diabetic complications, numerous studies have utilized proteomic approaches, which have been reviewed in great detail (6). Pathology of diabetic complications is associated with increased generation of reactive oxygen species (ROS) resulting in oxidative, glycooxidative and carbonyl stress (7). Following engagement with receptor for AGE (RAGE), advanced glycation endproducts (AGEs) induce the generation of ROS and activation of the transcription factor $\mathrm{NF}-\kappa \mathrm{B}$, causing changes in gene expression (8). AGEs are also known to affect the activity of several plasma proteins. For example, $50 \%$ aspartate aminotransferase enzyme activity is inactivated as a result of glycation (9). Similarly, impaired activity of glycated $\alpha$-1-antitrypsin was observed in diabetes, thereby leading to protease-antiprotease imbalance (10). Glycated transferrin demonstrated the deterioration of antioxidant capacity in diabetic patients (11). Additionally, glyco-oxidative modification leads to protein aggregation resulting in protein instability. To prevent serious metabolic disturbances caused by the accumulation of glyco-oxidatively modified proteins, these proteins are further degraded by the proteasomal system (12). Glyco-oxidative modification of protein results in the elicitation of autoantibodies against several diabetic plasma proteins. These proteins include albumin, insulin, carbonic anhydrase and heat shock proteins, thereby resulting in their decreased levels in diabetic plasma (13). However, any variation in insulin levels affects the insulin-regulated protein synthesis of several proteins. For example, decreased insulin synthesis and resistance in diabetes affects the gene expression of albumin and fibrinogen $(14,15)$. These factors contribute to differential protein expression. To compensate for the altered protein function and loss, enhanced or altered gene expression may occur, resulting in varying levels of proteins in diabetes.

Previous studies have reported differential expression of various proteins in diabetes, including $\alpha$-1-antitrypsin, fibrinogen, vitamin D binding protein, complement $\mathrm{C} 3$ and apolipoprotein A1 (Apo A1) (16-19). However, it is important to study differential protein expression in PCD to under- 
Table I. Parameters evaluated in CD, ND and PCD for 2DE, western blot and LC-MSE analysis.

\begin{tabular}{lcccccc}
\hline Subjects & $\begin{array}{c}\text { Fasting plasma } \\
\text { glucose }(\mathrm{mg} / \mathrm{dl})\end{array}$ & HbA1c $(\%)$ & $\begin{array}{c}\text { Serum creatinine } \\
(\mathrm{mg} / \mathrm{dl})\end{array}$ & $\begin{array}{c}\text { HDL } \\
(\mathrm{mg} / \mathrm{dl})\end{array}$ & $\begin{array}{c}\text { Triglycerides } \\
(\mathrm{mg} / \mathrm{dl})\end{array}$ & $\begin{array}{c}\text { Cholesterol } \\
(\mathrm{mg} / \mathrm{dl})\end{array}$ \\
\hline ND & $87.9 \pm 11.7$ & $5.5 \pm 0.3$ & $0.7 \pm 0.05$ & $50.6 \pm 5.6$ & $91.0 \pm 22.6$ & $145.1 \pm 15.4$ \\
CD & $92.8 \pm 11.55^{\mathrm{a}}$ & $7.2 \pm 0.6^{\mathrm{a}}$ & $0.8 \pm 0.02^{\mathrm{a}}$ & $42.7 \pm 6.2^{\mathrm{a}}$ & $116.3 \pm 19.2^{\mathrm{a}}$ & $146.0 \pm 14.0$ \\
PCD & $187.3 \pm 23.7^{\mathrm{b}}$ & $9.9 \pm 1.0^{\mathrm{b}}$ & $1.1 \pm 0.17^{\mathrm{b}}$ & $33.0 \pm 2.1^{\mathrm{b}}$ & $219.3 \pm 16.8^{\mathrm{b}}$ & $200.0 \pm 30.3$ \\
\hline
\end{tabular}

Data are shown as the mean $\pm \mathrm{SD} ;{ }^{\mathrm{a}} \mathrm{P}<0.005$, vs. ND; ${ }^{\mathrm{b}} \mathrm{P}<0.05$, vs. CD. 2DE, two-dimensional gel electrophoresis; $\mathrm{LC}^{\mathrm{M}} \mathrm{MS}{ }^{\mathrm{E}}$, liquid chromatography-mass spectrometry; ND, non-diabetic; CD, controlled diabetic; PCD, poorly controlled diabetic; HDL, high density lipoprotein; HbAlc, glycated haemoglobin.

stand the pathophysiology associated with the development of diabetic complications. In the present study, we analyzed differential protein expression in the plasma of CD and PCD subjects using proteomic methods and validating the results by western and dot blot analysis. Analysis of PCD subjects has not previously been performed.

\section{Materials and methods}

Chemicals. Chemicals were obtained from Sigma-Aldrich (St. Louis, MO, USA) unless otherwise stated. Antibody against Apo A1 was purchased from Abcam, Cambridge, UK.

Clinical plasma sample collection. Blood samples were collected from diabetic patients at the Maharashtra Medical Research Society. Informed consent was obtained from all patients and the study was approved by the Joshi Hospital Ethics Committee. Fasting blood glucose and HbA1c levels were determined by using a glucometer (Bayer AG, Leverkusen, Germany) and in2it analyzer (Bio-Rad, Hercules, CA, USA), respectively. Plasma was obtained by EDTA treatment, followed by centrifugation at $1500 \mathrm{x} \mathrm{g}$ for $15 \mathrm{~min}$. The supernatant was stored at $-80^{\circ} \mathrm{C}$ until further use.

Plasma sample preparation. Based on HbA1c levels, plasma samples were grouped into ND $(<6.4 \%), \mathrm{CD}(7-8 \%)$ and PCD (8.8-12.3\%). Ten representative samples from each group were pooled and were used for proteomic analysis. Albumin and IgGs were depleted by using a PROTBA kit (SigmaAldrich) according to the manufacturer's instructions. Protein concentration was determined by using a Quick Start Bradford protein assay kit (Bio-Rad).

Two dimensional gel electrophoresis (2DE), image and western blot analysis. A depleted plasma protein sample $(100 \mu \mathrm{g})$ was solubilized in $125 \mu \mathrm{l}$ rehydration buffer containing $8 \mathrm{M}$ urea, $2 \mathrm{M}$ thiourea, 4\% CHAPS, $70 \mathrm{mM}$ DTT, $0.1 \% \mathrm{C} 7 \mathrm{BzO}$ and $1 \mu \mathrm{l}$ ampholytes ( $\mathrm{pH} 3-10)$. The solubilized sample was loaded onto 7-cm non-linear IPG strips ( $\mathrm{pH} \mathrm{4-7)}$ and rehydrated overnight. Isoelectric focusing was performed by using the Protean IEF Cell (Bio-Rad) followed by SDS-PAGE separation. Resolved proteins on $12.5 \%$ gel were visualized by CBB-R250 staining or by western blot analysis (using anti-Apo A1 polyclonal antibody). Stained gel images were captured using the GS 800 calibrated densitometer
(Bio-Rad). Image analysis was performed using PDQUEST advanced software (Bio-Rad).

Trypsin digestion. CBB-stained protein spots were excised and destained by washing with $50 \%$ acetonitrile (ACN)/50 mM ammonium bicarbonate. Proteins were reduced and alkylated by $10 \mathrm{mM}$ DTT and $55 \mathrm{mM}$ iodoacetamide, respectively, followed by overnight digestion with trypsin at $37^{\circ} \mathrm{C}$. Digested peptides were extracted with $5 \%$ formic acid in 50\% ACN and were reconstituted in $5 \mu 10.1 \%$ formic acid in $3 \% \mathrm{ACN}$.

Liquid chromatography-mass spectrometry $\left(L C-M S^{E}\right)$ analysis and protein identification. LC-MS ${ }^{\mathrm{E}}$ analysis was performed with $2 \mu \mathrm{l}$ peptide digest (100 $\mathrm{ng} / \mu \mathrm{l}$ concentration) by using nanoACQUITY UPLC online coupled to SYNAPT HDMS system (Waters Corp., Milford, PA, USA) equipped with a nanolockspray ion source with a flow rate of $300 \mathrm{nl} / \mathrm{min}$ (external lockmass standard: Glu-fibrinopeptide) as described by Cheng et al (20). Following $\mathrm{MS}^{\mathrm{E}}$ analysis, data were analyzed with Protein Lynx Global Server software (PLGS, version 2.4, Waters Corp.). Protein identification of processed samples was performed by database search against a human subset of UniProt containing 44,987 protein entries.

Dot blot analysis. Ten plasma samples from each ND, CD and PCD patient were diluted with PBS in 1:1,000 dilutions. The diluted sample $(2 \mu \mathrm{l})$ was spotted onto nitrocellulose membranes. The membrane was air dried and blocked for $2 \mathrm{~h}$ with $5 \%$ skimmed milk in TBS at $37^{\circ} \mathrm{C}$. The membrane was then incubated with anti-Apo A1 antibody $(1: 7,000)$ for $1 \mathrm{~h}$, washed twice with TBS-T (0.05\% Tween-20) and then incubated with biotinylated secondary antibody for $30 \mathrm{~min}$. Immunodetection was performed by incubating membranes with streptavidin-conjugated horseradish peroxidase and Sigmafast DAB substrate.

Statistical analysis. Experiments were performed in triplicate. Statistical analysis was performed by the Student's t-test. Data were expressed as the mean $\pm \mathrm{SD}$. $\mathrm{P}<0.05$ was considered to indicate a statistically significant difference.

\section{Results}

Differential plasma protein expression was studied in CD and PCD clinical plasma samples following analysis of fasting 
Table II. Protein identification and fold expression in CD, ND and PCD using 2DE followed by LC-MS ${ }^{\mathrm{E}}$ analysis .

\begin{tabular}{llccccccc}
\hline Spot no. & \multicolumn{1}{c}{ Protein name } & $\begin{array}{c}\text { Accession } \\
\text { number }\end{array}$ & $\begin{array}{c}\mathrm{MW} \\
(\mathrm{Da})\end{array}$ & $\begin{array}{c}\mathrm{pI} \\
(\mathrm{pH})\end{array}$ & $\begin{array}{c}\text { PLGS } \\
\text { Score }\end{array}$ & $\begin{array}{c}\text { Coverage } \\
(\%)\end{array}$ & $\begin{array}{c}\text { Fold change } \\
(\mathrm{CD} / \mathrm{ND})\end{array}$ & $\begin{array}{c}\text { Fold change } \\
(\mathrm{PCD} / \mathrm{CD})\end{array}$ \\
\hline 1 & $\alpha 1$ antitrypsin & $\mathrm{P} 01009$ & 46707 & 5.24 & 1130.88 & 34.92 & 0.78 & 1.05 \\
2 & Vitamin D binding protein & $\mathrm{P} 2774$ & 52929 & 5.23 & 7865.01 & 51.05 & 0.77 & 1.04 \\
3 & Fibrinogen $\gamma$ chain & $\mathrm{P} 02679$ & 51478 & 5.23 & 3187.94 & 31.78 & 1.87 & 1.08 \\
4 & Apolipoprotein A1 & P02647 & 30758 & 5.43 & 1290.93 & 32.20 & 0.5 & 0.6 \\
5 & Haptoglobin & P00738 & 25176 & 6.11 & 3442.24 & 48.52 & 1.64 & 1.03 \\
6 & Transthyretin & P02766 & 15877 & 5.39 & 9106.519 & 45.83 & 0.68 & 1.02 \\
\hline
\end{tabular}

2DE, two-dimensional gel electrophoresis; LC-MS ${ }^{\mathrm{E}}$, liquid chromatography-mass spectrometry; ND, non-diabetic; CD, controlled diabetic; PCD, poorly controlled diabetic.

A
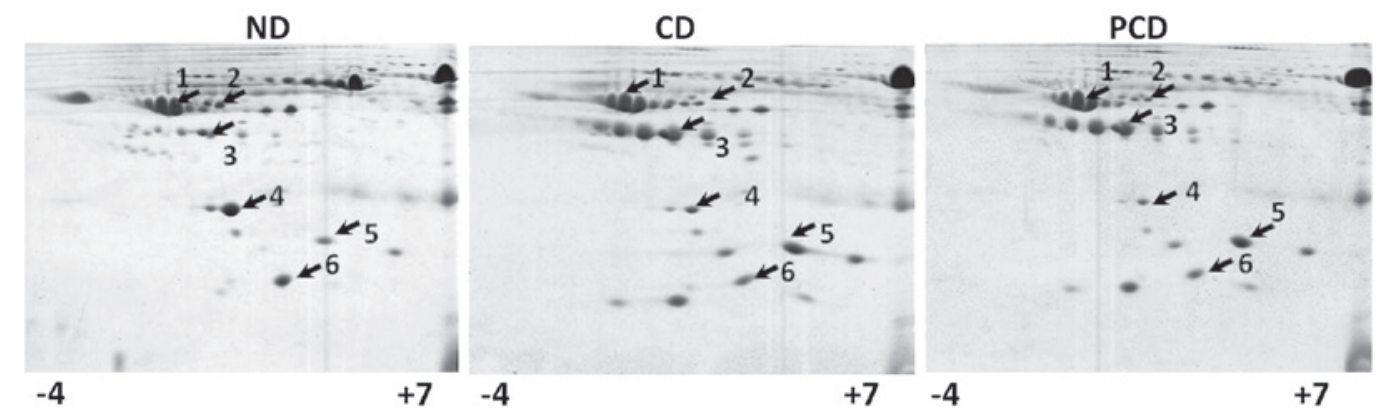

B
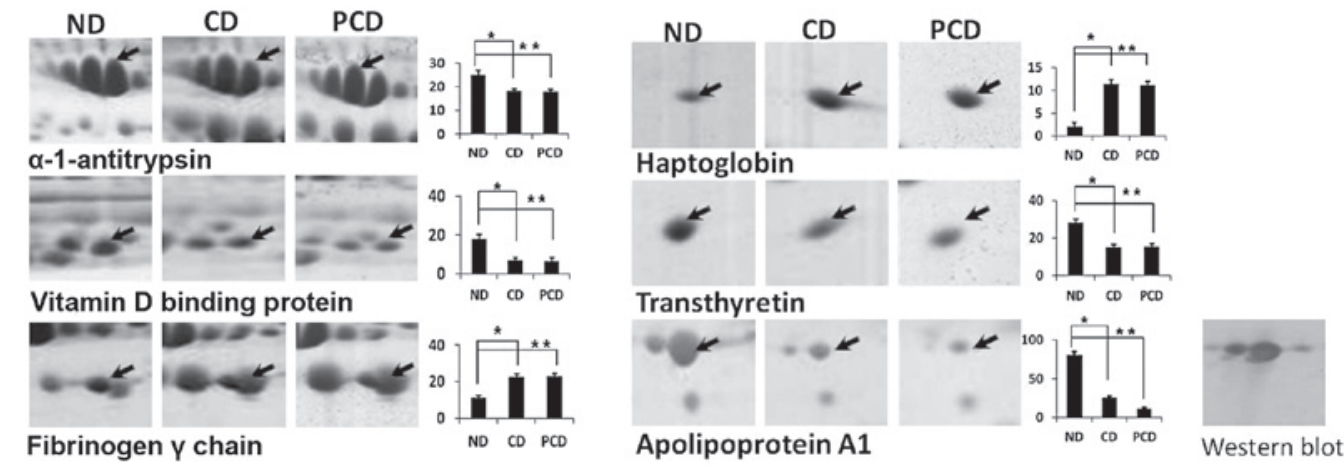

Figure 1. (A) 2DE analysis of ND, CD and PCD clinical plasma samples. (B) Densitometric analysis of differentially expressed proteins from ND, CD and PCD samples. ${ }^{*} \mathrm{P}<0.005$ compared with $\mathrm{ND} ;{ }^{* *} \mathrm{P}<0.05$ compared with $\mathrm{CD}$. $2 \mathrm{DE}$, two-dimensional gel electrophoresis; ND, non-diabetic; $\mathrm{CD}$, controlled diabetic; PCD, poorly controlled diabetic.

\begin{tabular}{|c|c|c|c|c|c|c|c|c|c|c|}
\hline B & 1 & 2 & 3 & 4 & 5 & 6 & 7 & 8 & 9 & 10 \\
\hline & $\theta$ & 0 & (2) & 0 & ( ) & 0 & 0 & 0 & 0 & (2) \\
\hline & 0 & 0 & 0 & $\theta$ & 0 & 0 & 0 & 0 & 0 & $\theta$ \\
\hline & 0 & $\theta$ & 0 & 0 & 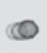 & 0 & (ㅇ & 0 & (c) & 0 \\
\hline
\end{tabular}

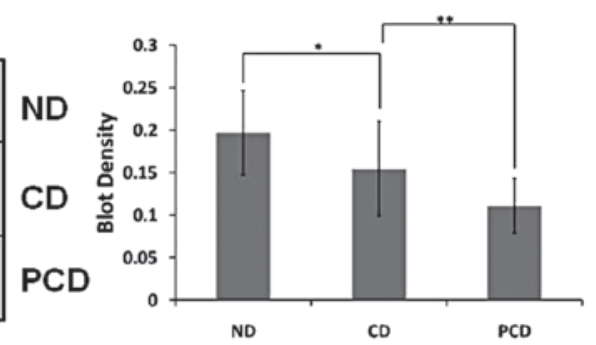

Figure 2. Dot blot analysis of ND, CD and PCD samples using anti-apolipoprotein A1 antibody. Significantly reduced levels of apolipoprotein A1 levels were observed in PCD compared with ND and CD. ND, non-diabetic; CD, controlled diabetic; PCD, poorly controlled diabetic; $\mathrm{B}, \mathrm{Blank}$. ${ }^{*} \mathrm{P}<0.05 ;{ }^{* *} \mathrm{P}<0.03$.

plasma glucose, HbAlc levels, serum creatinine, high density lipoproteins (HDL), triglycerides and cholesterol levels (Table I). Differentially expressed proteins were identified by 2DE and $\mathrm{LC}^{-\mathrm{MS}^{\mathrm{E}}}$ and are listed in Table II. Densitometric analysis of 2DE gels revealed upregulation of fibrinogen and haptoglobin and downregulation of vitamin D binding protein, $\alpha$-1-antitrypsin, transthyretin and Apo A1 in CD and PCD compared with ND samples (Fig. 1). However, no significant 
difference in differentially expressed proteins was detected between CD and PCD plasma with the exception of Apo A1, whose downregulation was more prominent in PCD. The observed downregulation of Apo A1 was validated by western blot analysis (Fig. 1) and dot-blot analysis of each clinical plasma sample from ND, CD and PCD (Fig. 2). Apo A1 downregulation in $\mathrm{PCD}$ was considered statistically significant $(\mathrm{P}<0.05)$.

\section{Discussion}

Diabetic plasma proteomic studies are important for understanding the molecular mechanisms which lead to complications. Numerous studies have been performed comparing ND and CD plasma samples (6). However, the pathophysiology of diabetic complications is demonstrated more clearly in PCD than CD. The present study was performed to identify differentially expressed proteins in PCD. Although fibrinogen, haptoglobin, VDBP, $\alpha$-1-antitrypsin and transthyretin were found to be differentially expressed in patients with diabetes, their levels were not significantly different between $C D$ and PCD. However, significant downregulation of Apo A1 was detected in PCD. Downregulation of Apo A1 is associated with the development of diabetic vascular complications mediated by the reverse cholesterol transport system (21). Decreased levels of Apo A1 in PCD may be attributed to numerous reasons, including autoantibodies against Apo A1 $(22,23)$, elevated levels of inflammatory molecules (24) and insulin resistance (25). The Apo B100/Apo A1 ratio predicts cardiovascular risk more accurately than the lipids, lipoproteins and lipid ratios (26) and the ratio increases in PCD compared with CD plasma (27). Furthermore, a negative correlation was observed between serum creatinine levels and Apo A1, which supports the incidence of chronic kidney disease with lower plasma HDL-cholesterol levels (28). Therefore, lower levels of Apo A1 in PCD may be associated with increased risk of cardiovascular and kidney disorders. Thus, downregulation of Apo A1 may serve as an early predictive marker for diabetic complications.

\section{Acknowledgements}

The authors thank Dr Vidya Gupta, Chair, Biochemical, for assistance in establishing collaboration with Joshi Hospital; Dr. A.M. Deshpande, Chairman of MMRS for his support and the Lady Tata Memorial Trust for Senior Research Fellowship. This study was carried out under CSIR network project NWP0004.

\section{References}

1. Anderson NL and Anderson NG: The human plasma proteome: history, character and diagnostic prospects. Mol Cell Proteomics 1: $845-867,2002$.

2. Anderson NL: The clinical plasma proteome: a survey of clinical assays for proteins in plasma and serum. Clin Chem 56: 177-185, 2010 .
3. Taylor R and Agius L: The biochemistry of diabetes. Biochem J 250: 625-640, 1988.

4. Chase HP, Jackson WE, Hoops SL, et al: Glucose control and the renal and retinal complications of insulin-dependent diabetes. JAMA 261: 1155-1160, 1989.

5. Takahashi S, Uchino H, Shimizu T, et al: Comparison of glycated albumin (GA) and glycated hemoglobin (HbAlc) in type 2 diabetic patients: usefulness of GA for evaluation of short-term changes in glycemic control. Endocr J 54: 139-144, 2007.

6. Sundsten T and Ortsater H: Proteomics in diabetes research. Mol Cell Endocrinol 297: 93-103, 2009.

7. Brownlee M: Biochemistry and molecular cell biology of diabetic complications. Nature 414: 813-820, 2001.

8. Giacco F and Brownlee M: Oxidative stress and diabetic complications. Circ Res 107: 1058-1070, 2010.

9. Bousova I, Bakala H, Chudacek R, et al: Glycation-induced inactivation of aspartate aminotransferase, effect of uric acid. Mol Cell Biochem 278: 85-92, 2005.

10. Hashemi M, Naderi M, Rashidi H, et al: Impaired activity of serum alpha-1-antitrypsin in diabetes mellitus. Diabetes Res Clin Pract 75: 246-248, 2007.

11. Mohammad TG, Mojtaba R and Mohsen R: Study of nonenzymatic glycation of transferrin and its effect on iron-binding antioxidant capacity. Iran J Basic Med Sci 13: 194-199, 2010.

12. Jung $\mathrm{T}$ and Grune $\mathrm{T}$ : The proteasome and its role in the degradation of oxidized proteins. IUBMB Life 11: 743-752, 2008.

13. Winter WE and Schatz DA: Autoimmune markers in diabetes. Clin Chem 57: 168-175, 2011

14. Tessari P, Kiwanuka E, Millioni R, et al: Albumin and fibrinogen synthesis and insulin effect in type 2 diabetic patients with normoalbuminuria. Diabetes Care 29: 323-328, 2006.

15. Peavy DE, Taylor JM and Jefferson LS: Correlation of albumin production rates and albumin mRNA levels in livers of normal, diabetic and insulin-treated diabetic rats. Proc Natl Acad Sci USA 75: 5879-5883, 1978.

16. Blanton D, Han Z, Bierschenk L, et al: Reduced serum vitamin D-binding protein levels are associated with type 1 diabetes. Diabetes 60: 2566-2570, 2011.

17. Ceriello A: Fibrinogen and diabetes mellitus: is it time for intervention trials? Diabetologia 40: 731-734, 1997.

18. Engstrom G, Hedblad B, Eriksson KF, et al: Complement C3 is a risk factor for the development of diabetes. A population-based cohort study. Diabetes 54: 570-575, 2005.

19. Lapolla A, Brioschi M, Banfi C, et al: On the search for glycated lipoprotein ApoA-I in the plasma of diabetic and nephropathic patients. J Mass Spectrom 43: 74-81, 2008.

20. Cheng FY, Blackburn K, Lin YM, et al: Absolute protein quantification by LC/MS(E) for global analysis of salicylic acid-induced plant protein secretion responses. J Proteome Res 8: 82-93, 2009.

21. Quintao EC, Medina WL, Passarelli M: Reverse cholesterol transport in diabetes mellitus. Diabetes Metab Res Rev 16: 237-250, 2000.

22. Vuilleumier N, Bas S, Pagano S, et al: Anti-apolipoprotein A-1 IgG predicts major cardiovascular events in patients with rheumatoid arthritis. Arthritis Rheum 62: 2640-2650, 2010.

23. Montecucco F, Vuilleumier N, Pagano S, et al: Anti-Apolipoprotein A-1 auto-antibodies are active mediators of atherosclerotic plaque vulnerability. Eur Heart J 32: 412-421, 2011.

24. Haas MJ, Horani M, Mreyoud A, et al: Suppression of apolipoprotein AI gene expression in HepG2 cells by TNF alpha and IL-1beta. Biochim Biophys Acta 1623: 120-128, 2003.

25. Mooradian AD, Haas MJ and Wong NC: Transcriptional control of apolipoprotein A-I gene expression in diabetes. Diabetes 53: 513-520, 2004.

26. Mallick KA, Joshi MR and Bhat PG: A study on Apo B100/Apo A-I ratio in uncontrolled type 2 diabetes mellitus. Int J Appl Biol Pharm Technol 2: 379-384, 2011.

27. Wagner AM and Ordonez-Llanos J: Apolipoproteins and prediction of fatal myocardial infarction. Lancet 359: 1863-1864, 2002.

28. Zoppini G, Targher G, Chonchol M, et al: Higher HDL cholesterol levels are associated with a lower incidence of chronic kidney disease in patients with type 2 diabetes. Nutr Metab Cardiovasc Dis 19: 580-586, 2009. 